\title{
A Pragmatic Analysis and Sociological Perspective on Pearl S Buck's The Good Earth
}

\author{
Rochmat Budi Santosa \\ STAIN Surakarta \\ Jl. Pandawa Pucangan Kartasura, \\ Sukoharjo, Central Java, Indonesia \\ b_santoz@yahoo.com
}

\begin{abstract}
This paper observes the struggle for life of East Asia people that was portrayed in the novel The Good Earth. The Good Earth is also portrayal of a true account experienced by its author, Pearl S Buck. She got inspiration from the life of farmer in China. She wrote this novel using the original name as the main character. Those names are Wang Lung and $\mathrm{O}$ Lan. They are couple and their life is on farm. The objectives of this study are to find the pragmatic and sociological aspects of the Novel. This research applies content analysis approach to understand the pragmatic and sociological life in Chinese society, especially in the novel. The finding of the study shows that the utterances in the novel reflect various speech acts i.e. expressive, assertive, commisive, persuasive, directive, and phatic. In the sociological aspect, the life of rural people in Chine is somewhat similar with that of in Indonesia. Otherwise, rural people have life style in common i.e. working hard, struggle for life, defending their belonging, and loving the nature.
\end{abstract}

Key words: pragmatic analysis, sociological perspective, Good Earth.

\begin{abstract}
Abstrak
Penelitian ini memaparkan perjuangan hidup para penduduk di Asia Timur yang disajikan pada novel bertajuk The Good Earth. The Good Earth juga merupakan gambaran kisah nyata pengalaman sang penulis, Pearl S. Buck. Dia telah mendapatkan inspirasi dari kehidupan seorang petani di China. Dia pun menulis novel ini menggunakan nama asli dari tokoh utama. Nama-nama tersebut adalah Wang Lung dan O Lan. Mereka berdua adalah pasangan suami istri yang tinggal di peternakan. Tujuan dari penelitian ini adalah untuk menemukan aspek-aspek pragmatik dan sosiologis dari novel tersebut. Dalam pelaksanaannya, penelitian ini menggunakan pendekatan analisis
\end{abstract}


konten guna memahami kehidupan masyarakat China secara pragmatik dan sosiologis, terutama dalam novel tersebut. Hasil penelitian ini menunjukkan bahwa ada beberapa ujaran dalam novel tersebut yang mencerminkan bermacam-macam speech act yang meliputi expressive, assertive, commisive, persuasive, directive, dan phatic. Dari segi sosiologis, kehidupan orang-orang pedesaan di China dapat dikatakan hampir sama dengan kehidupan masyarakat di Indonesia. Hal itu mencakup gaya hidup masyarakat pedesaan seperti umumnya, seperti kerja keras, penuh perjuangan untuk hidup, primpen terhadap apa yang mereka punya, dan kecintaan terhadap alam sekitar.

Kata Kunci: Analisis Pragmatik, Perspektif Sosiologi, Good Earth

\section{Introduction}

Survival is a term which occasionally occurs when talking about life in difficult circumstance. All of people in the world need something to survive. There are many kinds of necessity to fulfill the basic requirement in life, how they get those basic requirements, so they have to work. Almost all people in Asia work as a farmer to fulfill the necessity in their life, especially in China. In Chinese society, land is a source of life. Many people in China are farmers. Land is soul of Chinese society because China is an agricultural country. In agricultural country rice is the basic commodity, and other commodities are related to agriculture such as fruits and vegetables. The land or rice field is one of the most important things or basic element of agricultural country. According to Fung Yu - Lan "Agriculture and Trade "is like "Root and Branch "(1990: 22) based on this statement, in Chinese society agriculture is an important sector beside trade. The Good Earth novel tells about Chinese culture at the twenty century and agriculture has been the biggest power of the economy in China. It existed before machine and industry existed. 
One of the most popular ideologies that gave influence and altered Chinese mind was the theory of organic evolution. The theory says that there is a continuous struggle in every sector of live for the fittest species. In order to survive, the fittest species must be adaptable in environment and able to compete with other. When the Buck's novel was written, the Chinese ideology was communist.

Economy, social and culture developments create an opportunity for every citizen to seize the change to become wealthy. The rapid and ruthless competitive spirit at those periods made Chinese society lost their power to defend old tradition that had existed long time.

The Good Earth describes the condition of Chinese society. In this novel the social condition and economic life changed their life rapidly and radically. In Chinese society technology and science aspects were more influential in the city than in the village society. They defended the old tradition, being a farmer. The main character in this novel reflects it. He does not lose his tradition because he adheres to the traditional values, honoring his relatives.

The Good Earth is a story of a young man, named Wang Lung. He is about twenty years old. He lives off the land. He loves his land very much. The feeling toward his land is so strong. He likes to stay, brings roll of bread and garlic and stands to eat in his field. "And if he grew too weary in the day he laid himself into a furrow, and there, with the good warmth of his own land against his flesh, he slept "(Buck, 1971: 135).

In agriculture period people create viewpoints used to understand that view of success comes from different ways. The land is one of important things in an agriculture country. They always dream having a lot of land because land is what farmers are proud of. The dream is influenced by the condition of economy, society, culture, and ideology at the time. Thus it is 
understood that the environment influences an individual and individual influences the environment. Every body hope changes that brings in the glory and wealthy in their life. They made a great effort to be successful in their life. This condition could also be seen in Buck's The Good Earth.

Philosophers have different perceptions on wealth. These differences can be accommodated by looking at a material thing made up from parts of possessing many physical properties and other properties. "The physical properties are positioned in space and time, size, shape, duration, mass, velocity, solidity, inertia electric charge, spin, rigidity, temperature, harness and the like“(Encyclopedia of Philosophy, 1967: 179). In this context of meaning, the word has a derogatory flavor; people thinks that money, property, power, land and the like are the most important.

How a person expresses his perceptions on wealth is reflected on how he communicates with others. The way they communicate, then, can be traced pragmatically related to the social background.

\section{Pearl S Buck and Her Novel}

The Good Earth is one of epistolary novels that is very interesting to discuss. It is also a realistic novel that portrays the life of Chinese society in 1949. Pearl S Buck is one of novelist of the 20th century who was willing to examine her environment with a realistic eye and then reflected it in producing fiction. In Buck's writing, her life experiences inspired her with the idea of treating the life of a great Chinese farmer.

Buck's said:

"I get inspired from the figures of those people emerged first, above all others, in their simplicity and dignity and good nature. I saw Wang Lung, O Lan, their children, their farm house home, their struggle to live and enjoy life. They were the voiceless ones, though they and their kind made four fifths all China's people. I had seen abused by 
overloads taxed by governments. They were the ones who were at the mercy of famine and flood, which left their homes and wandered over the barren soil to find food that they might return again. Nothing could have persuaded them to leave the beloved land except the fear that if they did not they might die and so leave it forever. It was better to go to the rich southern cities and beg, though to beg sickened their souls, for they were people of independence. I knew many other people of China, too "(The Good Earth, 1971: vi).

Based on inspiration above, she writes The Good Earth. The figures of Wang Lung and O Lan became the characters in her novel's The Good Earth. The Good Earth was published in 1949 and became one of the bestsellers. Besides, it also gave thousand of American readers insight into life in country about which they knew little. The novel was made into a Broadway play and a film, also translated into many languages.

Pearl S Buck is not a Chinese but for a long time she had been living and studied in China because her parents were Christian missionaries that got an assignment in China, so she knew about the culture and society condition in China at the time. Pearl S Bucks was born on June 26, 1892, in Hilsboro, West Virginia. Her parent's Christian missionaries and Buck was raised in China, attending boarding school in Shanghai. In 1910, she went to America to attend Randolph - Macon Woman's College, in Lynchburg, Virginia.

After graduation, she soon returned to China, marrying an agricultural specialist in 1917, and living in North China. In the 1920s, Buck taught English literature at the University of Nanking. In 1925, she returned to America and received a Master of Arts degree from Cornell University in 1926. Back in China, Buck and her husband found their lives in danger when revolutionary army attacked Nanking. They spent a day in hiding before being rescued by Americans gunboats 
(http://nobelprizes.org/nobel_prizes/literature/laureates/1938/buck-bio. htm1).

Buck is an American novelist but she spent her life in China so her capability to write about the condition of the Chinese society at the time was not doubted. Buck remained a prolific writer for the remainder of her life. She published in all over seventy books. These include novels, short story collection, drama, poetry, children's literature and translations from the Chinese. One of her novels is The Good Earth.

The function of literature is to provide a just and lively image of human nature or at least who agree on the general proposition that the end of literature is some kind of illumination of the human situation (Daiches, 1982: 338).

The word of the good earth has a wealthy symbol. Wang lung is a farmer and he has land with a lot of nutrition, dark colored and it is a symbol of fertility. Everywhere, land having a lot of nutrition and fertility will bring wealthy in the next time. Hence, he keeps the soil fertile, takes care of his land for getting a wealthy and he loves his land. Actually he becomes a successful farmer and he gets wealthy from his land in the end of story. A farmer having good earth or land is something proud for himself.

This paper discuss about how struggle for life is portrayed through Wang Lung as the major character.

\section{Cognitive linguistics}

In the realm of cognitive linguistics, Janda (2000: 22), points out that at a recent ICLA (International Cognitive Linguistics Association) meeting the scholar "Suzanne Kemmer specifically devoted her talk to summarizing achievements [in cognitive linguistics] to date and suggesting 'areas ripe for exploration with cognitive concepts and methods'. At the top of her list is sociolinguistic variation". 
But what exactly is cognitive linguistics? Escandell-Vidal (1996:

634) provides an excellent description of three main ideas on which cognitive linguistics is based:

First, the idea that the mind is a symbolic system: as human beings, we need to map all our perceptions of the persons, objects and events in the real world on to internal representations; our knowledge can be seen, thus, as a set of assumptions. Second, the idea that human knowledge is highly structured: our internal representations do not merely form a list, but a complex network of sets of organized items. Third, the idea that perception, behaviour and understanding depend crucially on previous knowledge. These are common assumptions in cognitive psychology and artificial intelligence, and have proved relevant also for explaining natural language processing by humans.

Escandell-Vidal proposes that "social aspects of communication have to be explained in terms, not of inferential patterns working on universal principles but of the structure and contents of specific knowledge: the emphasis is to be put especially on context, and not on inferential devices" (Escandell-Vidal 1996: 640). Context, she claims, is related to knowledge: "In our minds, previous utterances, extra linguistic situations and encyclopedic knowledge all have the same status: they are all internal representations. This opens the possibility for a cognitive pragmatics of social action: social and situational aspects of communication are interesting to cognitive pragmatics because they are mapped on to mental representations" (Escandell-Vidal 1996: 640).

In her conclusion, Escandell-Vidal (1996: 645) suggests that social behavior reflects systematic knowledge specific to the culture in which the language is spoken.

Cognitive linguistics is a theoretical framework that derives from the assumption that language is based on our experience of the world as human beings. Constructions in language emerge as a result of the way we as 
humans perceive the world around us. Humans map their perceptions of people, objects, and events onto internal representations. Knowledge is structured; what we know does not form a list of facts but a network of information linked in various ways. Further, perception and understanding are dependent on embodied experience (Escandell-Vidal 1996: 634).

\section{Research Method}

In this research paper, the data are analyzed by describing Wang Lung' speech in Buck's The Good Earth. The data analysis steps consist of several process, they are as follows:

a. The researcher identified and recorded the inventory data from the novel.

b. The inventory data were categorized in accordance with the theme that emerge. After making category, the researcher checked and rechecked the categorized data to get the most appropriate data to the research study.

c. The second step was data interpretation. The researcher explained the data with his interpretation. The data were analyzed from the perspective of pragmatics and then the researcher made some inferences. The data inferences here were conclusion that was based on the interpretation of the data analysis. Finally, the data analysis led to the research findings.

\section{Discussion}

\section{The portraits of Wang Lung in The Good Earth}

China is part of Asia countries, there are many commodities come from agriculture sector such as rice, wheat, and corn. China - in the setting of time 
in The Good Earth - was an agriculture era. Agriculture sector is the main sector of China beside trade because many people of China are farmers. Land is one of important thing in agriculture country. On the other hand, the science of Chinese is about agricultural. Wang Lung is a common people of China as a farmer. Hence, he considers that land is important thing in his life.

Wang Lung is a farmer. On the other hand, his life always relates to agriculture. Wang Lung is a poor farmer in his village. The name of his village is Ahwei. He does not have a lot of land. He gets his land from legacy of his parents. He is a good farmer. He always gives more attention for his land. He always works hard for his land everyday. In the early morning, he goes to his field. He uses the yoke of ox to help him plough his land after he harvests his grain in the field. He ploughs his western field for planting garlic and union. He goes to his home when the sun stucks the zenith.

In reality he worked as he had always worked. He put his hoe upon his shoulder and he walked to his plots of land and he cultivated the rows of grain, and he yoked the ox the plough and he ploughed the western field for garlic and union. But the work was luxury, for when the sun struck the zenith he could go to his house and food would be there ready for him to eat, and the dust wiped from the table, and the bowls and the chopsticks placed neatly upon it (Bucks, 1971: 26).

The quotation above is the portrait of Wang Lung's struggle for life in The Good Earth. He tries to get what he wants. He hardly attempts to make his land fertile. He hopes his land gives him good harvest. Hence, he works hard to get the perfect result because he considers that the land has values in his life. The fertility of the land brings wealth to him so he cultivates his land with all of his capability. He hopes that the land gives him wealth because he always pays attentions to his land. It is shown when he works hard in his land. 
Wang Lung is a farmer so he fulfills the necessity in his life from his field. Hence, he must work hard to get it. He believes that his land gives him wealth next time. Wang Lung always works hard in his field everyday. He always digs up paddy fields looking for necessity for his life and family. He works hard until his back feels sick. "One day when Wang Lung was hard pressed with the swelling wheat and was cultivating it with his hoe, day after day, until his back throbbed with wearing ness...“(Buck’s, 1970:28). He does not feel tired when he works in his field because he works sincerely and he loves his land. He hopes his land gives him good harvest and takes him in wealth. He can expand his land again.

\section{Pragmatics analysis}

(1) Wang Lung: "I shall have a red coat on him and red flowered trousers and on his head a hat with a small gilded Buddha sewn on the front and on his feet tiger - faced shoes. And I will wear new shoes and a new coat of black sateen " (Buck's, 32).

The context: When the first son was born, he is very busy to prepare of his child's birth. He wants to buy clothes and shoes for him. He has money from selling a sack of rice in the grain shop. He uses this money to buy clothes, coat and his son's shoes. This quotation shows that he fulfills his life necessities from the result of his harvest in the field. He sells his harvest in the grain shop in town and then he changes his harvest with money. He can buy clothes and food with his money.

Interpretation: It is a commisive utterance that he promises to himself to buy many things for his new born baby.

(2) Wang Lung fells happy. "A first - born son," He said proudly (Buck's,:38). 
Wang Lung lives in his village. He is a farmer. He feels that God gives him life in the world. A son was born from his wife. He has the first son from his wife. He may not look happier. He thinks that the world full of malignant spirit. The malignant spirit can disturb in his life. It does not bring fortune in his life. "He thought of this at first with joy and then with a pang of fear. It did not do in this life to be too fortunate. The air and earth were filled with malignant spirits who could not endure the happiness of mortals, especially of such as are poor " (Buck, 1971:38). He fells happy because he has son in his life. What he has done, he thanks to his God. He fells proud. He has son because the son symbolizes the luck in the culture of Chinese.

(3) Wang Lung: "If I have a handful of silver it is because I work and my wife works, and we do not, as same do, sit idling over a gambling - table or gossiping on doorsteps never swept, letting the fields grow to weeds and our children go half - fed!" (Buck's, 59).

The context of the utterance is when his uncle comes in Wang Lung's field. At that time he is working on his paddy field. His uncle comes to ask for money. His uncle asks some money for him, he is like little boy but Wang Lung does not care. He always persuades his nephew to give money. Wang Lung does not stop to work. He takes a pity to look at him and then he gives some money for him. He knows that his money is spent on the gambling table.

Interpretation: The speech uttered by Wang Lung indicates that he indirectly persuades his uncle to work, not only do gambling.

(4) Wang Lung: "They cannot take the land from me. The labour of my body and the fruit of the fields I have put into that which cannot be taken away. If I had the silver, they would have taken it. If I had bought with the silver to store it, they would have taken it all. I have the land still, and it is mine "(Buck's, 70). 
The context is his neighbors come to his house again. They enter to the house looking for food. Wang Lung cannot do anything, he just look at his neighbors searching his house. He stands in front of the door. He is forced by his uncle to give a small heap of bean and a handful of corn. Actually, he will give food for his children, father and himself. His uncle shows that one of Wang Lung's children is fat. He proves that his nephew has a lot of food in the house.

Interpretation: this expression of anger is quite clear. He expresses his feeling directly that he does not permit his people take everything he has. He also uses conditional sentence to make indirect proposition

(5) Wang Lung: Come, woman, we will go south” (Buck’s, 75).

The context is when Wang Lung said to his wife that they will go to the southern city exactly in Kiangsu city. They go to southern city to flee from famine and dryness disaster in his village. The possessive feeling to his land is brought in Kiangsu.

Interpretation: He calls his wife woman to show that they are really intimate and he expects his wife to go with him.

(6) Wang Lung: I will not sell my land, ' (Buck’s, 81).

The Context: He does not like other people in his village that gives his land easily to someone from the town. Although his family feels hungry, he will not sell his land to anyone. He looks at them one by one and he is very angry with them. It is shown that Wang Lung defends his land. Although he cannot plant anything in his field, he will not sell his land. He loves his land so much.

Interpretation: It is declarative sentence to show that he has firm character. 
(7) Wang Lung: "If I had anything to sell I would sell it and go back to the land. Or if were not for the old head, we would walk though we starved. But how can he hand the small child walk a hundred miles? And you with your burden! " (Buck's, 110).

The context is when Wang Lung lives in Kiangsu, he always remembers and thinks about his land. He feels that his land is waiting for him. He knows that his village has been poured by rain in this month and the land becomes fertile. Then he goes back to the hut and he says roughly to his wife. The strong feels of his land makes him always miss for his land. He wants to sell everything and goes back to the land but he does not have anything to sell. Even if his father and his children are able to walk a hundred miles but they cannot walk as far as a hundred miles.

Interpretation: This is a conditional sentence, Wang Lung utters something that is hard to realize, but he has a great spirit.

(8) Wang Lung: 'On such a day as this.' He said aloud to his father the fields should be turned and wheat cultivated' (Buck's, 110).

The context is he feels he cannot survive again in the southern city. He really wants to go home in Ahwei. It is the name of his village. He always remembers and thinks of his land as long as he lives in Kiangsu. Kiangsu is the name of the southern city. When in the evening wind blows on his face for the moment, he feels a mighty longing for his field. He tells his father that on such a day the fields must be cultivated by wheat. He loves his land. His felling appears when he feels he cannot survive again in the southern city.

(9) Wang Lung: "If I had the gold and silver and the jewels, I would buy land with it, good land and I would bring forth harvests from the land! "(Buck's, 116). 
Wang Lung goes to southern city. He avoids famine disaster in his village. He lives in southern city. He lives in the hut. There are many huts in the southern city. He listens to dialogue among the people near his hut. They talk about their life after that he talks about their dreams. They dream when they have much money and gold, what they will do with their money and gold. For the moment, Wang Lung suddenly says; It shows that Wang Lung considers that there is nothing important than the land in his life. The land is more valuable than gold, money or silver. Land becomes priority in his life.

(10) Looking at his wife with strange eyes, Wang Lung cries out at her: "Now any one looking at you would say you were the wife of a common fellow and never of one who has land which he hires men to plough! " (Buck's, 160).

Wang Lung's behavior and life style changed after he becomes a landlord and also his lifestyle. He becomes consumptive and then is also practise polygamy. At the first meeting with Lotus in the great tea - shop, it makes pioneer affair between Wang Lung and Lotus. Lotus makes him ignore his wife. His land gives the wealth. In reality, the wealth brings negative impact to him. He has affair with the girl who meets him in the great tea - shop. Since he meets Lotus in that place, he feels that his wife does not look beautiful anymore. He begins to insult his wife. He feels bored with his wife when he looks her body. There is nothing beautiful on his wife's body. He finds the beauty in Lotus because woman symbolizes beauty but he does not find it in his wife. Wang Lung feels that his wife just gives him the children but she does not take care of his body. He says so without thinking about her feeling. He ignores the feeling of his wife after he becomes a landlord. His wife thought that she does not suit for him. In fact, his wife is loyal to him. She never asks anything to him. She gives him children from her womb. 
(11) Wang Lung looks at her and said loudly; "I mean, cannot you buy a little oil your hair other women do and make yourself a new coat of black? And those your wear are not fit for a land prop rioter's wife, such as you now are "(Buck's, 161).

He looks at his wife. She does not have something special in her body and then he looks at wife's hair. Her hair does not look beautiful. She seldom gives shampoo on her head. She never makes up his face and also gives a little oil on her hair. She never wears good dress like any other women do. She does not look like as the wife of landlord in her village. He considers that his wife is not suitable for landlord's wife. He looks of his wife like wife of farmer, not wife of landlord.

(12) Wang Lung says to his wife; "I have laboured and have grown rich and I would have my wife look less like a hind "(Buck' 161).

He has worked hard and he is rich man in his village. He has lots of lands everywhere and he can rent labors to work in his field. He wants his wife looks beautiful when other person looks at her. It makes him proud himself when he has a beautiful wife. On the other hand, he admits that he is a landlord in his village.

(13) Wang Lung; "My uncle is one of the Red breads" (Buck's, 219).

The context is when Wang Lung has become a rich man in his village but he feels no calm in his house. He has a lot of land. His lands give him good harvest. Thus, he can change his harvest with money and save some in the warehouse. He worries when the robber comes to his house and then they take everything in his house. Everyday he thinks his problem because he cannot fight against the robber alone. He is surprised knowing that the leader of the robber is his uncle. His uncle lives together in his house. The name of 
the robber is red breads. He will stay at home although the robbers come to his house. He does not want to leave his house moreover his land. He will choose to die than leaving his land.

Interpretation: He knows that his uncle is the robber but he doesn't want to take any risk of giving his wealth to other people. He will defends his belongings from anyone who wants to rob, including to his own uncle.

(13) Wang Lung: "On the same day we will bury these two dead from our house and I will take a good piece of my hill land and we will bury them there together and when I die I will be laid there also "(Buck's, 253).

The context is when Wang Lung's wife and Ching die in his village. Wang Lung's wife is a good woman. Ching is a faithful servant and also his neighbor. They are the people that he loves during his life in the world. His love is like he loves his land. Both leave him from the world and they sleep forever. He feels sad. His wife dies because she has incurable disease. Ching dies because he is old. Wang Lung gives his good earth for funeral to them. When he dies he wants his body buried in his land and together with his wife and Ching.

Interpretation: From the quotation above, it shows that he loves his land so much. He wants to be buried in his land when he dies next day.

(14) Wang Lung curses his God. He says "Now that old man in heaven will enjoy himself, for he will look down and see people drowned and starving and what the accursed ones likes " (Buck's, 257).

Wang Lung disavows his enjoyment that is given from his God. He is angry when his lands get flood disaster. The land that he loves much was attacked by flood disaster. All of his lands are full of water. He is against curse of his God when his lands attacked by flood disaster. Wang Lung's 
behavior shows that he is a possessive person to his lands. It makes him materialistic because he considers that land is part of his life because Wang Lung is a good farmer. In this case land is part of matter.

\section{Conclusion}

The utterance used in communication among people seems to be universal. The utterance must be interpreted in term of in what context the conversation takes place. In the context of rural people in the novel The Good Earth, the speech act used in the conversation varies from direct to indirect speech act. The direct speech acts which are mostly used by the people who have similar social status are also mostly found in this novel. The pragmatic analysis can help readers understand the society. People in the society have speech community in which the social aspects of group's people can emerge. The novel proves it.

\section{References}

Brenann, Joseph Gerad. 1967 . The Meaning of Philosophy. New York: Harper \& Row publisher.

Buck S, Pearl. 1971. The Good Earth. Great Britain: Methuen and CO. LTD. London.

Edwards, Paul. 1967. The Encyclopedia of Philosophy. USA: Mcmillan, Inc.

Muktazam, Rethinking Rural Development Approaches to Ensure Human Security in Asia: Lesson learnt from Indonesia, Thailand and Malaysia.

http://nobelprizes.org/nobel_prizes/literature/laureates/1938/buck-

bio.htm1(Accessed on May 25 ${ }^{\text {h }}$ 2007.23. 30 PM). 